\title{
Technological characterisation of roofing slate from Nepal
}

\author{
*Victor Cardenes ${ }^{1}$, Naba Raj Neupane ${ }^{2}$, Lalu P. Paudel ${ }^{3}$, Veerle Cnudde ${ }^{1}$, Jean Pierre Cnudde ${ }^{1}$ \\ ${ }^{1}$ UGCT/PproGress, Department of Geology and Soil Science, Ghent University, Krijgslaan 281/S8, 9000 Ghent, Belgium \\ ${ }^{2}$ Department of Environmental Science, Amrit Campus, Tribhuvan University, Kathmandu, Nepal \\ ${ }^{3}$ Central Department of Geology, Tribhuvan University, Kathmandu, Nepal \\ (Email: victor.cardenes@ugent.be)
}

\begin{abstract}
Roofing slate is a group of natural stones which can be split into thin, large and regular tiles. The world's slate market is the third in importance for natural stone, just after granite and marble. Most of the world's production of roofing slate is concentrated in Spain. There are new emerging countries (Brazil, China, India and Nepal) with huge resources of roofing slate. However, many of these resources are not yet well studied. Nepalese slate industry is still incipient, although most of the houses have been constructed using roofing slate since historic time. The representative three samples were taken for quality assessment from Tanahun and Baglung districts. From a geological point of view, the productive formations are the Benighat Slates and Nourpul Formation, but other formations are likely to be potential slate sources. Previous studies have shown an important reserve of slate which needs detailed investigation. Petrography and mineralogy of representative Nepalese slates are similar to the rest of the world's roofing slate. The test results showed values within the acceptance thresholds for roofing slates. This paper also compares the Nepalese slates with other varieties of roofing slates from Spain. Roofing slate industry of Nepal is promising, but still there are many points to improve.
\end{abstract}

Keywords: Roofing slate, non-mechanised quarry, diamond wire, quality control, EN 12326

Paper Received: 16 June 2015

Paper Accepted: 06 February 2016

\section{INTRODUCTION}

Roofing slate is the commercial term for a group of natural stones which shares the characteristic of being able to split into thin, thick and plane tiles. There are many different rocks which may have these characteristics, such as shales, slates, sandstones, phyllites, schists and cinerites, among others (Cárdenes et al. 2014). Nowadays roofing slate is the third natural stone traded in the world, just after carbonate rocks and granite (Fig. 1). The main producer is Spain, followed by China, Brazil and Canada, while the main consumers are, in order, France, United Kingdom, Germany and the USA. The slate market is closely linked to the behaviour of the general construction market. In Europe and the USA, this market has suffered the recent economic crisis which has slow down the rate of construction. Still, these markets have not fully recovered. On the other hand, the new emerging countries, like China, Brazil and India, are continuously increasing their rates of construction. These countries are the new potential targets for the roofing slate market.

In case of Nepal, the country has proved slate outcrops (Neupane and Paudel 2007, 2012) in Tharpu area, western region, but an in-existent slate market. However, there are more than 31 locations identified for slate occurrences and more than 100 local primitive quarries have been practicing to supply roofing slate in Nepal since long time. Almost 75\% houses and shades in hilly districts of far western Nepal (e.g. Darchula,
Dadeldhura, Doti, Baitadi, Bhajang, Accham, Bajura) are using roofing slates, about $40 \%$ houses and shades in eastern and mid western Nepal (e.g. Sindhupalchok, Ramechhap, Dhankuta, Rukum, Rolpa and Jajarkot), and about 20\% houses in western and central Nepal (Palpa, Syangja, Parbat, Baglung, Tanahun, Dhading and Nuwakot) are using roofing slate. At present, the demand of roofing slate is increasing in the developed market. The statistical database from the United Nations (UN 2014) shows a trade of few hundred thousand dollars for the last years. Regarding the incipient mining practice in Nepal, this analysis focused on the three representative varieties of Nepalese slate from a technological point of view, comparing the obtained data with data from Spanish slates, the most used slates in the world.

\section{GEOLOGICAL CONTEXT AND SAMPLES}

The Himalaya can be divided into five distinct morphogeotectonic zones from south to north (Stocklin 1980). From an economic point of view, the southernmost Terai Plain is potential for gravel, sand, groundwater, petroleum and natural gas. The Sub Himalaya is the potential area for construction materials, radioactive minerals, petroleum, natural gas and minor amount of coal. The Lesser Himalaya is potential for metallic and non-metallic minerals, gemstones, dimension stones (roofing slates) and voluminous construction materials. 

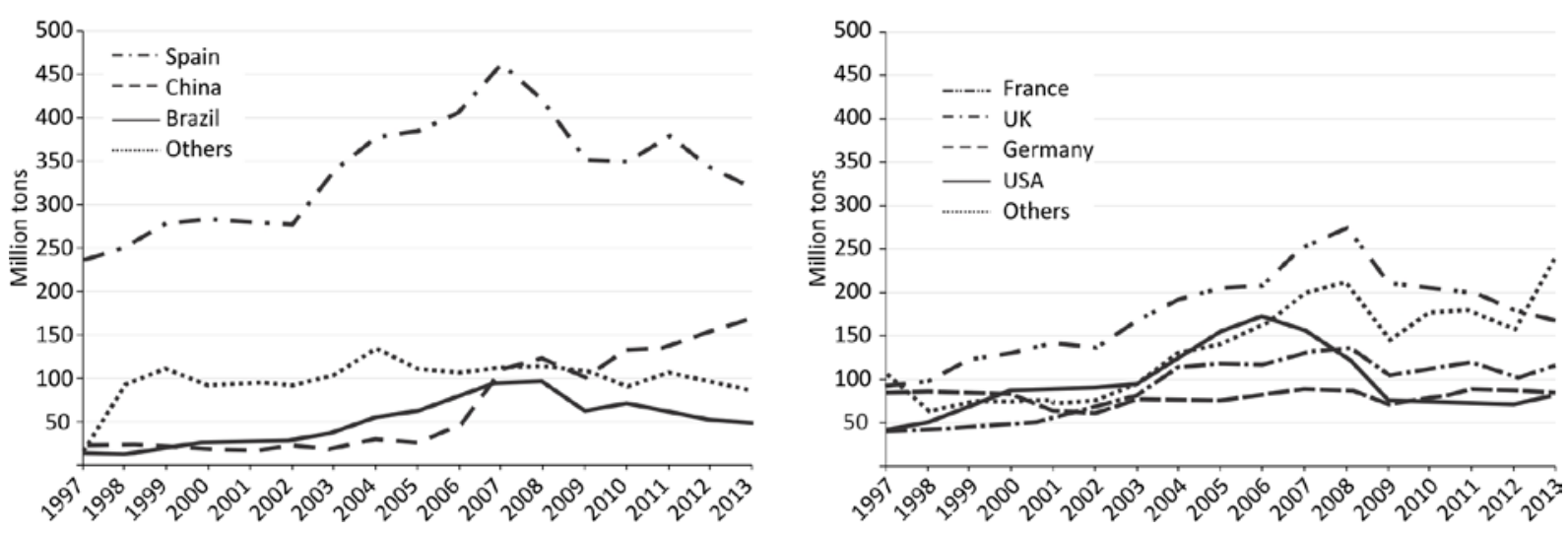

Fig. 1: Left: World's exports of roofing slates by countries for the period 1997-2013. Right: World's imports of roofing slates for the same period. Source: United Nations Comtrade Database (http://unstats.un.org, code 6803).

The Higher Himalaya is promising for precious and semiprecious stones, marble and metallic minerals like lead, zinc, and uranium, gold. The Tibetan Tethys Zone is prospective for limestone, gypsum, and natural gas (Kaphle 2011). The Lesser Himalaya in central Nepal is made up of the late Pre-Cambrian to early Palaeozoic rocks of the Nawakot Complex and is divided into the Lower and Upper Nawakot groups (Stocklin 1980). Those lithostratigraphic units can be recognised also in the western Lesser Himalaya and is studied by many geologists (Fuchs and Frank 1970, Hagen 1969, Hasimoto et al. 1973, Sakai 1985, Sharma et al. 1984). The collected samples belong to Nourpul Formation (Late Precambrian) and Benighat Slates (Early-Paleozoic) of the Nawakot Complex. Out of three parts of Nourpul Formation, the lower part is composed of light-grey to white quartzites intercalated with phyllites and slates. The middle part comprises grey to black slates and green to purple phyllites, frequently in alternation with pink to grey calcareous quartzites. The upper part is made up of light, pink to creamy dolomite, highly fractured. The Benighat Slates is composed of carbonaceous slates with carbonates predominantly in the lower part whereas biotitic slates with quartz veins intercalation in the thrust zone area.

The collected samples from Bandipur, Tanahun district and Bhakunde, Baglung district belong to the Nourpul Formation, and Tarakhola Khani, Baglung district belongs to the Benighat Slates. The geographical location of the sample of Bandipur is Lat. 27 $55^{\prime} 53^{\prime \prime} \mathrm{N}$ and Long. 84 24'22" E,

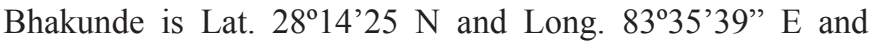
Tarakhola Khani is Lat. $28^{\circ} 16^{\prime} 01^{\prime \prime} \mathrm{N}$ and Long. 8331'35 E.

\section{MINING OF ROOFING SLATES}

Mining of roofing slate is a rather simple process, since the raw materials do not require a special transformation. In a mechanised quarry, slate blocks are sawed with diamond wire machines. The diamond wire has the important advantage of greatly reducing the fractures generated by other methods for stripping the slate, like gunpowder. The blocks have the maximum dimensions of the truck load that will bring them to the factory. At the factory, blocks are sawn again into smaller slabs that can be handled by the workers. The slabs are split into tiles one by one, by a skilled worker, and then formatted with mechanical scissors according the market standards. There are several standards in the market, being the most popular rectangular models and German models, which have special shapes (Cárdenes et al. 2014). Once the tiles are finished, they are carefully stacked in crates, ready for shipping.

In a non-mechanised quarry (Fig. 2A), the processes are much simpler. Slate blocks are stripped by hand, with the help of iron bars, and so always following the dip direction of the layer. This task is rather dangerous, and may lead to serious injuries for the workers. Blocks are then smaller that in a mechanised quarry, and they are sawn and split at the quarry using chisels and hammers (Fig. 2 B, 2C and 2D). The formatting is done at the same time, using scales and templates. The personnel are composed by people who usually have other works, like agriculture, and complete their wage working at the quarry.

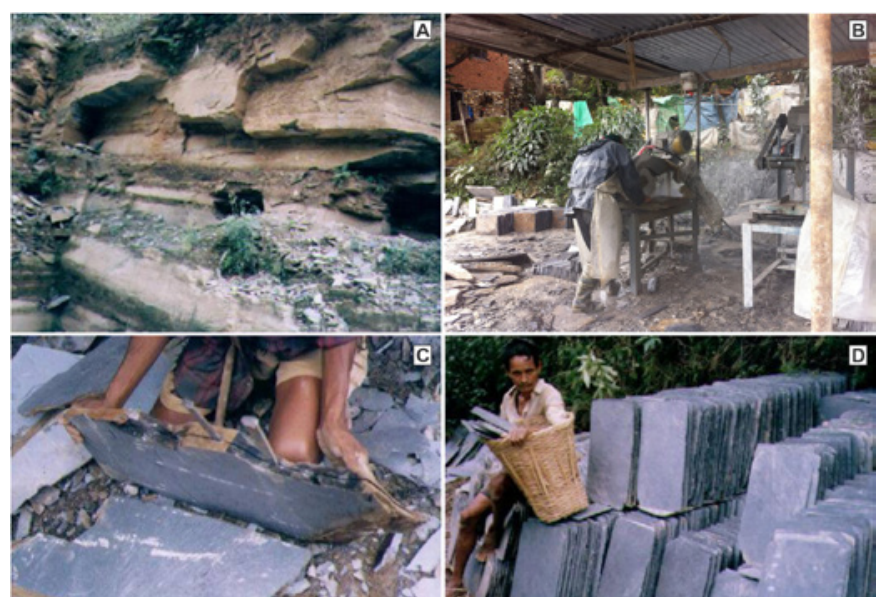

Fig. 2: Images of slate mining in Nepal. A: Mining site at Bandipur. B: Sawing and formatting of slate blocks. C: Hand-splitting of slate tiles. D: Slate tiles ready for transportation. 


\section{NORMATIVE CHARACTERISATION}

As other construction materials, roofing slates must accomplish specific technical requirements, according to standardised tests. The most popular norms that apply to roofing slates are the European Norms (EN 12326-1 and -2) and USA Norms ASTM (C406, C120, C121, C217). The European Norms are a-compendia of the previous norms that each country had developed, and give only information about the properties and characteristics of the slate. The ASTM norm C406 goes a step further, and estimates a service life up to 75 years for the slate tiles, according to the test results. However, the lifespan of a roofing slate greatly depends on climatic and meteorological factors (average temperature, rain, hailstone incidence, etc.), and these factors should be taken into account when estimating that lifespan. Other countries have also their own regulations on roofing slate, like India (IS: 6250-1981). The Indian norm is rather old, but has many points in common with the EN and ASTM norms. Then, roofing slate norms are made according to the specific conditions of each country or region, taking into account the traditional architecture.

In order to check the constructive properties of the Nepalese roofing slate, several weathering tests were developed on the Nepalese samples, according with the EN 12326-2 and ASTM norms:

- $\quad$ Water absorption (EN 12326-2 part 11)

- Determination of non-carbonate carbon content (EN 12326-2 part 13)

- Determination of carbonate content (EN 12326-2 part 14)

- $\quad$ Sulphur dioxide exposure (EN 12326-2 part 15)
- $\quad$ Thermal cycle (EN 12326-2 part 16)

- $\quad$ Petrographic analysis and X-ray diffraction (EN 12326-2 part 17)

Results were compared with reference data obtained from Spanish roofing slates (data from the Laboratory of the Technological Slate Center, Sobradelo de Valdeorras, Spain) according to the EN 12326-2 norm. The values correspond to the mean of the data obtained during the years 2011 and 2012. These reference slates come from the Ordovician terrains of the Truchas Syncline, nowadays origin of most of the current slate production in the World (Cárdenes et al. 2014).

\section{Technological Tests}

Water absorption, thermal cycles and exposure to $\mathrm{SO}_{2}$ were performed at the Laboratory of the Geology and Soil Science Department at Ghent University. Results of technological tests according to EN 12326 (Table 1) showed similar values compared to the reference data, with some exceptions. For the water absorption, Tarakhola Khani and Bhakunde have low values, but not Bandipur, which presented a value of $0.7 \%$. According to EN 12326, slates with more than $0.6 \%$ of water absorption are considered to be vulnerable to freeze-thaw, so should be submitted to the freeze-thaw test. However, this test was not performed for this research.

Regarding the non-carbonate carbon and carbonate contents, all the slate samples presented values below the reference values. For the weathering tests, i.e. thermal cycles and exposure to $\mathrm{SO}_{2}$, the Nepalese slates showed no alteration at all, obtaining the best score in both tests.

Table 1: Results of the analysis for the selected samples of Nepalese slates, together with the reference results obtained from Spanish slates. All the tests were performed according to EN 12326-2.

\begin{tabular}{|c|c|c|c|c|c|}
\hline Sample locations & $\begin{array}{c}\text { Water } \\
\text { absorption }\end{array}$ & $\begin{array}{l}\text { Non-carbonate } \\
\text { carbon content }\end{array}$ & $\begin{array}{c}\text { Carbonate } \\
\text { content }\end{array}$ & Thermal cycle & $\begin{array}{c}\text { Exposure to } \\
\mathrm{SO}_{2}\end{array}$ \\
\hline Bandipur & $0.70 \%$ & $0.16 \%$ & $<0.01 \%$ & $\mathrm{~T} 1$ & $\mathrm{~S} 1$ \\
\hline Bhakunde & $0.08 \%$ & $0.28 \%$ & $0.74 \%$ & $\mathrm{~T} 1$ & $\mathrm{~S} 1$ \\
\hline Tarakhola & $0.32 \%$ & $0.22 \%$ & $<0.01 \%$ & $\mathrm{~T} 1$ & $\mathrm{~S} 1$ \\
\hline Reference (Spanish Slates) & $0.29 \%$ & $0.31 \%$ & $0.78 \%$ & T1-T2 & S1-S2 \\
\hline
\end{tabular}

Other important test is the Modulus of rupture that corresponds to part 10 of EN 12326. For this work, no data were obtained from the Nepalese slate samples. The mean values for the Spanish reference samples are 50.7 $\mathrm{MPa}$ and 44.4 MPa for longitudinal and transversal directions. For these varieties of slates, Neupane and Paudel (2012) mention values between 59.8 and $37.3 \mathrm{MPa}$ for the longitudinal direction, and between 35.2 and 50.6 MPa for the transversal direction; and found according to the norm ASTM C170.

\section{Petrographical analysis and X-ray diffraction}

The petrographical analyses of the three samples were performed with an optical microscope Zeiss Axioskop A.1. Instead of performing the examination in three orthogonal sections, as stated in EN 12326-2, it was considered enough representative examination of one section, parallel to the direction of the slaty cleavage.

- Sample from Bandipur is a shale/anchimetamorphic slate, a rock with very high deformation (almost a mylonite) but 
not so high temperature. This can be seen in the matrix, very abundant, in which is possible to recognise the original sedimentary texture. Also, there are some isolated crystals of authigenic muscovite and clasts of igneous origin (Fig. 3).

- Sample from Bhakunde shows more sedimentary features than Bandipur, with a lot of deformation but low recrystallisation of the matrix, which still keeps sedimentary muscovite. Most of the quartz clasts have a thin film of chlorite, result of the deformation. Some of these quartz clasts are of volcanic origin, showing corroded surfaces. This rock can be also considered as a shale/ anchimetamorphic slate (Fig. 3).

- Tarakhola sample is a phyllite/quartz-schist, with an important strain component and lepidoblastic texture (Fig. 3). Rock is mainly composed by biotite, quartz and occasionally plagioclase. There is also chlorite in the matrix, due to later retro-metamorphism processes.

In the samples Bandipur and Bhakunde, no clear traces of metamorphism were found, i.e., development of metamorphic blasts. No iron sulphides were found in the three samples. It was not possible to calculate the Mica Stacking Index according to
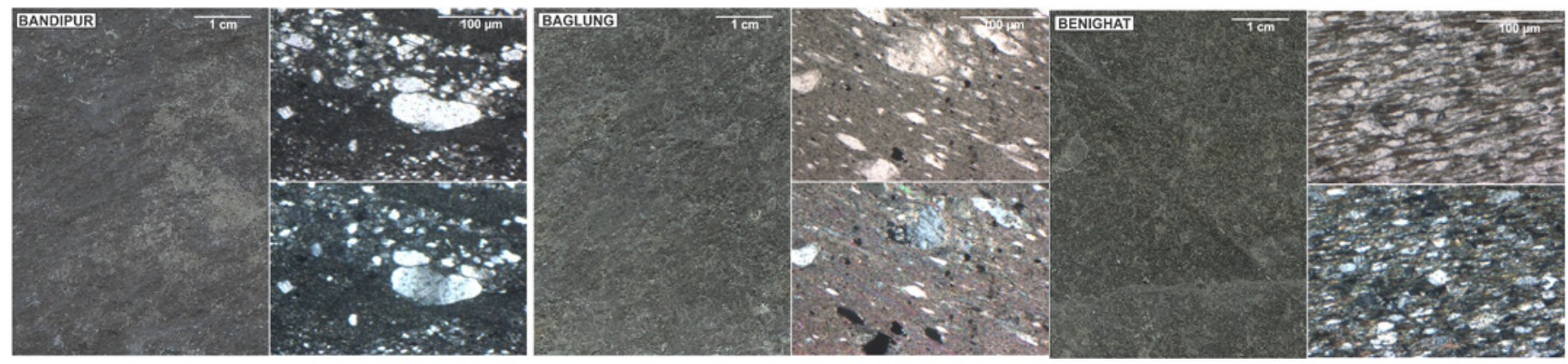

Fig. 3: Macro and microscope images of the slate samples. The micro images consists in the same section taken with plane parallel polarised light (up) and crossed polarised light (down).

EN 12326-2 (Cárdenes et al. 2010), due to the lack of clear mica alignments.

The X-ray diffraction analyses were performed at the facilities of the Geology Department of the Ghent University with a Bruker D8 Advance Eco. The angular scan was recorded from 3 to $60^{\circ} 2 \theta$, at a $0.01^{\circ} 2 \theta$ step size. Obtained data were processed with the Xpowder software (v. 2004.04.44). The resulting data (Table 2, Fig. 4) showed a typical mineral composition for a standard roofing slate (Cárdenes et al. 2014).
Table 2: XRD semi-quantification of the main mineralogical phases present.

\begin{tabular}{|c|c|c|c|c|}
\hline Location & Quartz & Mica & Chlorite & Biotite \\
\hline Bandipur & 42.1 & 40.4 & 17.4 & 0.0 \\
\hline Bhakunde & 58.1 & 24.7 & 17.2 & 0.0 \\
\hline Tarakhola & 54.4 & 0.0 & 0.0 & 45.6 \\
\hline
\end{tabular}

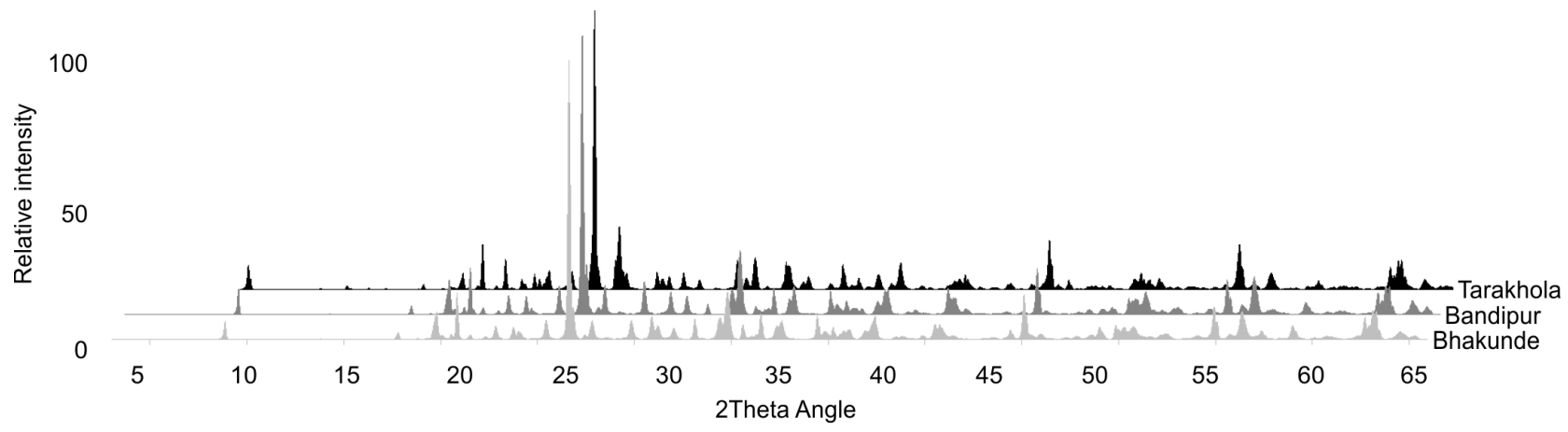

Fig. 4: Stacked diffractograms resulting of the Nepalese slate samples, showing the typical shape for roofing slates.

Nepalese roofing slates cannot be considered slates from a petrological point of view. However, this does not mean that they are not suitable for roofing. As pointed before, any rock able to be split into thin and plane tiles can be used for roofing. However, each set of norms have its own definition of roofing slate, which are very similar but not identical. According to ASTM C119 Standard terminology relating to dimension stone, a slate is a microcrystalline metamorphic rock in which the micaceous minerals have sub-parallel orientation, origin of the cleavage. This definition is very similar to that found in the IS 6250-1981. On the other hand, EN 12326 distinguishes between slates of tectonic origin and compressional origin, accepting then slates with no visible or evident traces of metamorphism. Regarding the Nepalese slates, they fit in the definition of the three norms. 
No weathering minerals (carbonates or iron sulphides) were found, achieving the best results in the weathering tests of EN 12326. However, the water absorption content is rather high for the Bandipur slate, which may lead to trouble in cold environments. Regarding the mechanical behaviour no reliable data were obtained.

\section{CONCLUSIONS}

Nepalese slate samples analysed in this research work showed good technological characteristics. Petrography and mineralogy of representative slates are similar to the rest of the World's roofing slate. The test results showed values according to the acceptance thresholds for roofing slates. However, other important features, such as quality control during fabrication and regularity of sizes and shapes were not checked. Roofing slate industry from Nepal is promising, but still there are many potential places to explore quality and reserve estimation. The lack of infrastructures and facilities seriously hinders the development of the roofing slate industry. Local and national government, together with private companies, should join efforts and invest in enhancing an industrial fabric for this valuable resource.

\section{REFERENCES}

Cárdenes, V., Rubio-Ordoñez, A., López-Munguira, A., de la Horra, R., Monterroso, C., Paradelo, R., and Calleja, L., 2010, Mineralogy and modulus of rupture of roofing slate: Applications in the prospection and quarrying of slate deposits. Engg. Geol., v. 114, pp. 191-197.

Cárdenes, V., Rubio-Ordoñez, A., Wichert, J., Cnudde, J. P., and Cnudde, V., 2014, Petrography of roofing slates. Earth-Sci Rev., v. 138, pp. 435-453.
Fuchs, G. and Frank, W., 1970, The geology of west Nepal between the Rivers Kali Gandaki and Thulo Bheri. Geologische Bundesanstalt, Wien, $103 \mathrm{p}$.

Hagen, T., 1969, Report on the geological survey of Nepal. v. 1, Preliminary reconoissance.

Hasimoto, S., Ohta, Y., and Akiba, C., 1973, Geology of the Nepal Himalayas. Saikon Publishing, Tokyo.

Kaphle, K. P., 2011, Minerals, mines and mining activities in Nepal. Natural Resources, Development and Environmentalism in Nepal. http://kpkaphle.blogspot. com/2011/12/minerals-mines-and-mining-activities-in. html.

Neupane, N. R. and Paudel, L. R., 2007, Quality assessment, reserve estimation and economic analysis of roofing slate in the west central Lesser Himalaya. Jour. Nepal Geol. Soc, v. 36 (Sp. Issue), pp. 17-17.

Neupane, N. R. and Paudel, L. R., 2012, Quality and economic aspects of roofing slates in the Tharpu Area, Tanahu. Bull. Dept. Geol., Tribhuvan University, Kathmandu, Nepal, v. 14, pp. 43-50.

Sakai, H., 1985, Geology of Kaligandaki Supergroup of the Lesser Himalaya in the Nepal. Mem. Fac. Sci. Kyoto Univ., Ser. D (Geology), v. 25, pp. 337-397.

Sharma, T., Kansakar, R., and Kijaki, K., 1984, Geology and Tectonics of the region between Kali Gandaki and Bheri rivers in central west Nepal. Bull. Coll. Sci., University of the Ryukyus, v. 38, pp. 57-102.

Stocklin, J., 1980, Geology of Nepal and its regional frame. Jour. Geol. Soc., v. 137, pp. 1-34.

UN, 2014, http://unstats.un.org, United Nations Comtrade Database, code 6803. 